\title{
Eräitä Englannin väestöpolitiikan saavutuksia ja tavoitteita
}

Kirjoittanut Usko Waismaa.

\section{Johdanto.}

Väestöpolitiikka tähtää aina pitkälle eteenpäin, minkä vuoksi sen tulokset eivät ole heti nähtävissä. Hyviin tuloksiin pyrittäessä on välttämätöntä ottaa väestöpoliittiset näkökohdat huomioon kaikissa sosiaalisissa ja taloudellisissa tulevaisuudensuunnitelmissa. Englannissa on päädytty siihen tulokseen, että menestyksellinen väestöpolitiikka edellyttää monia sellaisia toimenpiteitä, jotka ovat omiaan kasvattamaan ja luomaan kokonaan uuden ja terveen 'suhtautumisen perheellisyyteen. Ne voivat vaikuttaa kuitenkin vasta vähitellen. Sen vuoksi siellä on ollut välttämätöntä ryhtyä eräisiin kiireellisiin toimenpiteisiin tapahtuneiden vaurioiden korjaamiseksi. Nämä toimenpiteet kohdistuvat osaksi perheiden taloudelliseen tukemiseen ja osaksi, edelliseen läheisesti liittyen, perheellisten olosuhteiden parantamiseen erilaisten, yhteiskunnan äideille ja lapsille tarjoamien palvelusten avulla. Taloudellista tukea suunniteltaessa ja annettaessa on lähdetty siitä, että perheellisyydestä ei saa tulla mitään hyötyä tuottavaa taloudellista yritystä. Toimenpiteet tähtäävätkin perheen taloudellisten taakkojen huojentamiseen eikä mihinkään palkintojen antamiseen. Päämääränä on, että käytäntöön otetut tukemismuodot auttaisivat 
kunnollisia vanhempia kasvattamaan ja elättämään kolme-neljä lasta sellaisissa olosuhteissa, että heistä kasvaisi terveitä ja vastuuntuntoisia kansalaisia.

\section{Lapsilisäjärjestelmä.}

Perheiden taloudellisessa tukemisessa on lapsilisäjärjestelmällä huomattava osuus. Englannin lapsilisäjärjestelmä pohjautuu Beveridge-raportissa esitettyyn suunnitelmaan, jonka mukaan kaikille olisi taattava välttämätön toimeentulo. Suurille perheille ei palkka kuitenkaan yksin riitä toimeentuloa turvaamaan. Sen vuoksi niille olisi annettava lapsilisää. Perheen aiheuttamat kustannukset on kuitenkin jaettava valtion ja vanhempien kesken. Tämän vuoksi raportissa esitettiinkin, että perheen ensimmäisestä lapsesta ei maksettaisi lainkaan lapsilisää.

Lapsilisälaki hyväksyttiin kesäkuun 15 päivänä 1945 , ja sen mukaisia lapsilisiä alettiin maksaa elokuun 6 päivästä 1946 alkaen. Englannissa lapsilis ä (family allowance) on luonteeltaan vähän toisenlainen kuin meillä ja sananmukaisesti sitä suomen kielessä vastaisikin nimitys perhelisä. Mainitun lain 1 $\S:$ ssä sanotaan, että lapsilisä suoritetaan perheen hyväksi yhtenä kokonaisuutena (ei siis nimenomaan lasten hyväksi kuten Suomessa). Edellä mainitun periaatteen kanssa jossain määrin ristiriitainen on kuitenkin se lain määräys, että lapsilisä Englannissakin maksetaan perheen äidille eikä koko perheen toimeentulosta huolehtivalle perheen isälle.

Lapsilisänä suoritetaan 5 shillinkiä viikossa jokaisesta 15 vuotta nuoremmasta lapsesta perheen vanhinta lasta lukuun ottamatta. Jos lapsi 15 vuotta täytettyään on vielä koulussa tai ammattiopissa, maksetaan hänestä lapsilisää 31 päivään seuraavaa heinäkuuta hänen täytettyään 16 vuotta.

Lapsilisän saamisen edellytyksenä on, että ainakin toinen vanhemmista on Englannin kansalainen ja syntynyt maan alueella tai asunut siellä ainakin 52 viikkoa kahden vuoden kuluessa. Ulkomaalaiselle voidaan suorittaa lapsilisää, jos hän on asunut maassa 156 viikkoa neljän vuoden aikana. 
Lapsilisä suoritetaan postin välityksellä siten, että sen saajalle annetaan shekkivihko, jossa on lapsilisän määräinen shekki jokaista viikkoa varten. Postitoimisto lunastaa shekit kunakin tiistaina. Shekit ovat kuitenkin voimassa kuuden kuukauden ajan, joten niitä ei välttämättä tarvitse muuttaa rahaksi heti. Normaalitapauksessa sisältää shekkivihko koko vuoden shekit.

Lapsilisää saa nykyisin noin 2970000 perhettä ja siihen oikeutettujen lasten lukumäärä on noin 4700000 . Lapsilisä maksetaan kokonaan valtion varoista, ja sen aiheuttamat kustannukset ovat noin 60 milj. puntaa vuodessa. Lapsilisä ei ole veroista vapaata tuloa, kuten meillä on asian laita.

Lapsilisän määrä oli Beveridge-raportissa esitetty suuremmaksi kuin 5 shillinkiä viikossa. Nykyistä, pienempää lapsilisän määrää perusteltiin sillä, että lapset saavat vapaan koulumaidon ja -aterian muodossa valtiolta melkoisen lisäavustuksen ja että voimassa olevan tukipalkkiojärjestelmän johdosta perheet saavat kutakin perheenjäsentä kohden huomattavan alennuksen elintarvikkeiden hinnoista. Tukipalkkioihin on nimittäin käytetty noin 450 milj. puntaa vuodessa.

Englannin väestökomitea on maaliskuun 18 päivänä 1949 päivätyssä mietinnössään pitänyt lapsilisäjärjestelmän edelleen kehittämistä välttämättömänä. Se huomauttaa, että lasten kasvaessa suuremmiksi nousevat myös niiden elatuskustannukset. Tämän vuoksi lapsilisän määrän tulisi olla suurempi 11-vuotiaiden ja sitä vanhempien lasten osalta. Samalla komitea pitää lapsilisän määrän korottamista yleensäkin tarpeellisena. Komitea ehdottaakin, että lapsilisä olisi korotettava 7 shillinkiin viikossa alle 11-vuotiaista lapsista ja 10 shillinkiin viikossa 11 vuotta täyttäneistä lapsista. Sitä paitsi komitea katsoo, että heti kun taloudelliset olosuhteet sen sallivat, lapsilisää olisi alettava suorittaa myös perheen ensimmäisestä lapsesta. Lapsilisän määrän korottaminen olisi kuitenkin tärkeämpää kuin sen ulottaminen ensimmäistäkin lasta koskevaksi. Jälkimmäinen toimenpide tietäisi lapsilisämenojen lisääntymistä 68 milj. punnalla vuodessa, jolla määrällä lapsilisän nykyinen määrä voitaisiin korottaa yli kaksinkertaiseksi. Komitea 
esittää myöskin, että lapsilisä olisi vapautettava veroista. Mainitut komitean asettamat tavoitteet ovat vielä toistaiseksi saavuttamatta.

\section{Lapsivähennykset verotuksessa.}

Lapsilisän ohella tuetaan lasten vanhempia verohelpotuksilla. $\mathrm{Ne}$ ovat olleet käytännössä vuodesta 1909 lähtien. Perheenhuoltaja saa tehdä määrätyn vähennyksen verotettavasta ansiotulostaan jokaisesta alle 16-vuotiaasta lapsesta ja sitä vanhemmastakin lapsesta, jos tämä vielä jatkaa koulunkäyntiään. Lapsivähennyksen suuruus on nykyisin 60 puntaa vuodessa lasta kohden. Lapsivähennyksistä verotuksessa saavat käytännöllistä hyötyä vain ne, joiden tulot ovat siksi suuret, että he joutuvat suorittamaan niistä tuloveroa. Määrätyn tulorajan alapuolelle jääville ei vähennysoikeudesta ole mitään etua. Niillekään, jotka lapsivähennyksen voivat tehdä, ei sen tuottama hyöty aina ole 60 puntaa lasta kohden, elleivät tulot nouse niin suuriksi, että vähennysoikeus voidaan täysimääräisenä ottaa huomioon. Suuremmissa tuloluokissa jää lapsivähennyksen merkitys suhteellisesti pienemmäksi kuin alemmissa tuloluokissa, koska vähennyksen määrä on sama kaikille tuloista riippumatta.

Jo mainittu väestökomitea on pohtinut myös kysymystä verovähennyksistä. Alempiin tuloluokkiin kuuluvien asemaa se ehdottaa parannettavaksi siten, että lapsilisä määrättäisiin verovapaaksi tuloksi. Varsinaista lapsivähennysjärjestelmää olisi komitean mielestä korjattava siten, että nykyinen 60 punnan lapsivähennys jäisi edelleen voimaan lapsivähennyksen minimimääränä, mutta että ansiotuloista saataisiin kutakin lasta kohti vähentää 10 prosenttia aina tuhannen punnan tuloihin saakka ja sen yli nousevista vuosituloista 5 prosenttia, kuitenkin siten, että korkein sallittu vähennys olisi 150 puntaa lasta kohden.

\section{Aitiysavustukset.}

Aitiysavustukset ovat Englannissa nykyisin järjestetyt elokuun 1 päivänä 1946 annetussa yleisessä kansanvakuutuslaissa. Niitä ei 
siis makseta suoraan valtion varoista, kuten meillä, vaan on äitiysavustuksen saamisen edellytyksenä, että hakija täyttää kansanvakuutuslaissa säädetyt edellytykset, ts. että hän tai hänen miehensä on suorittanut säädetyn määrän viikottaisia vakuutusmaksuja.

Aitiysavustuksia on kolmea eri laatua:

1) Äitiysraha (maternity grant), neljä puntaa jokaisesta syntyneestä lapsesta. Sen tarkoituksena on auttaa yleisissä synnytyskuluissa sekä lapsen vuoteen ja vaatteiden hankinnassa.

2) Hoitoavustus (attendance allowance), joka on yksi punta viikossa synnytystä lähinnä seuraavien neljän viikon aikana. Sen tarkoituksena on auttaa kodinhoitoavun palkkaamista synnytyksen jälkeen.

3) Aitiyslisä (maternity allowance), suuruudeltaan 36 shillinkiä viikossa. Tämä maksetaan normaalitapauksissa 13 viikolta, nimittäin 6 viikolta ennen synnytystä, synnytysviikolta sekä 6 viikolta sen jälkeen.

A itiysrah a n saminen perustuu joko äidin omaan tai hänen aviopuolisonsa vakuutukseen, ja se edellyttää vakuutusmaksujen suorittamista ainakin 26 viikon ajalta. Aitiysraha maksetaan jokaisesta syntyneestä lapsesta. Jos lapsi syntyy kuolleena, mutta raskaus on kestänyt ainakin 28 viikkoa, maksetaan äitiysraha kuitenkin. Jos syntyy kaksoset, maksetaan äitiysraha kummastakin lapsesta. Aitiysraha suoritetaan yleensä heti synnytyksen jälkeen, mutta anomuksesta voi sen saada aikaisemminkin. Sitä voidaan anoa etukäteen aikaisintaan 11 viikkoa ennen laskettua synnytysaikaa. Äitiysrahaa on anottava viimeistään kolmen kuukauden kuluessa synnytyksestä lukien.

Hoitoavustuksen saaminen pohjautuu sekin joko äidin tai hänen aviopuolisonsa vakuutukseen. Vakuutusmaksujen suorittamista koskevat vaatimukset ovat samat kuin äitiysrahan suhteen. Hoitoavustusta on anottava ennen synnytystä tai 28 päivän kuluessa sen jälkeen. Jos vakuutettu isä on kuollut, voidaan hänen vakuutuksensa perusteella anoa ja saada hoitoavustusta, jos kuolemasta synnytyspäivään ei ole kulunut enempää kuin 310 vuorokautta. Hoitoavustusta ei makseta, jos anoja parasta aikaa 
saa sairausavustusta, työttömyysrahaa, tapaturmakorvausta tai leskeysavustusta.

A i tiys 1 is ä voidaan suorittaa ainoastaan äidin oman vakuutuksen perusteella. Sen saaminen edellyttää, että äiti on ollut työssä tai työttömäksi tahi sairaaksi rekisteröitynä ainakin 45 viikkoa 52 viikosta ennen äitiyslisän saamista ja että hän on maksanut ainakin 26 vakuutusmaksua. Kun äitiyslisän maksaminen alkaa 6 viikkoa ennen synnytystä, on sitä anottava ainakin kuusi viikkoa ja aikaisintaan 11 viikkoa ennen synnytystä. Jos anomus tehdään kuutta viikkoa myöhemmin, maksetaan äitiyslisä vasta anomispäivästä alkaen. Åitiyslisän saaminen edellyttää lisäksi, että äiti ei käy työssä sinä aikana, jolta hän saa avustusta. Jos synnytys tapahtuu odotettua myöhemmin, jatkuu äitiyslisän suorittaminen keskeytyksettä ja päättyy vasta kuusi viikkoa synnytyksen jälkeen. Tällaisissa poikkeustapauksissa äitiyslisää siis suoritetaan pitemmältäkin jaksolta kuin 13 viikolta.

Äitiysavustuksia saavien lukumäärä oli ensimmäisen vakuutusvuoden 5.7.48-4.7.49 aikana noin 650000 . Käytännöllisesti katsoen nämä kaikki saivat äitiysrahan, $7 / 8$ heistä sai lisäksi hoitoavustuksen ja $1 / 8$ äitiyslisän. Äitiysavustusten yhteinen rahamäärä oli mainittuna aikana pyörein luvuin $10 \mathrm{milj}$. puntaa.

Koska äitiysraha ja hoitoavustus voidaan maksaa joko äidin tai hänen aviopuolisonsa vakuutuksen perusteella, käsittää tämä järjestelmä suurin piirtein kaikki äidit. Joku pieni määrä äitejä jää kuitenkin ilman mitään avustusta, esim. niissä tapauksissa, joissa äiti ei ole avioliitossa eikä myöskään työssä. Esim. opiskelijat eivät kuulu vakuutettuihin eivätkä siis voi saada äitiysavustustakaan.

Kuten aikaisemmin on mainittu, lapsilisää ei suoriteta perheen ensimmäisestä lapsesta. Ensimmäisen lapsen aiheuttamat kustannukset ovat kuitenkin sangen huomattavat, eikä äitiysraha riitä niitä peittämään. Vuonna 1946 suoritetun tutkimuksen mukaan vaihtelivat ensimmäisen lapsen aiheuttamat kustannukset $31-57$ punnan välillä. Mainituista menoista eivät lääkäri- ja sairaalakulut muodostaneet suurinta osaa, vaan muut menot kuten vaatetus, vuode, lastenvaunut y.m. Näihin menoihin käyttivät virka- 
ja ammattimiehet noin 36 puntaa, työmiehet noin 28 puntaa ja

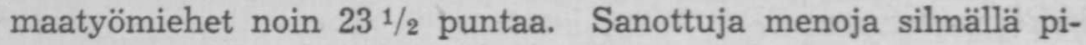
täen on tulevaisuuden tavoitteeksi esitetty, että niin kauan kuin ensimmäisestä lapsesta ei suoriteta lapsilisää, siitä olisi maksettava jokin kertakaikkinen summa, joko lapsilisäjärjestelmän yhteydessä tai korottamalla äitiysrahaa. Ensimmäisestä lapsesta suoritettava äitiysraha on ehdotettu nostettavaksi 4 punnasta 15 puntaan, josta 10 puntaa olisi maksettava kuusi viikkoa ennen synnytystä ja loput heti synnytyksen tapahduttua. Tällainen äitiysrahan korotus aiheuttaisi vuodessa 4 milj. punnan lisämenon.

\section{Kunnalliset kodinhoitajat.}

Kodinhoitopalvelun järjestäminen ei ole mikään uusi tulokas Englannin väestöpolitiikassa, joskin se vasta viime vuosina on saavuttanut laajemmat mittasuhteet. Jo vuonna 1936 yleistä terveydenhoitoa koskeva laki oikeutti paikalliset terveydenhoitoviranomaiset palkkaamaan apulaisia auttamaan odottavia tai sairastavia äitejä, joilla oli 5 vuotta nuorempia lapsia. Myöhemmin, vuonna 1944, paikallisten viranomaisten valtuuksia laajennettiin ja heidät oikeutettiin palkkaamaan kodinhoitoapua myös muissa sairaustapauksissa. Näitä valtuuksia käyttivät kuitenkin hyväkseen vain suhteellisen harvat viranomaiset, eivätkä nekään aina hyvällä menestyksellä. Näytti olevan vaikeata saada sopivaa työvoimaa.

Mainitun epäkohdan poistamiseksi pidettiin välttämättömänä, että kodinhoitotyö tunnustettaisiin ammattityöksi ja että siihen antautuville taattaisiin kunnolliset työskentelymahdollisuudet ja säännöllinen työaika sekä asianmukaiset palkka- ja lomaedut. Ensimmäinen tälle pohjalle rakentuva kokeilu aloitettiin Oxfordissa vuonna 1944. Silloin vapaaehtoinen naisjärjestö, Women's Voluntary Services, yhteistoiminnassa Oxfordin kaupunginhallituksen kanssa järjesti uusimuotoisen kodinhoitopalvelun. Tämä uusi järjestelmä onnistui niin hyvin, että vuonna 1946 terveysministeriö suositteli kodinhoitopalvelun laajentamista yhteistoiminnassa mainitun naisjärjestön kanssa. Sen tuloksena monet kau- 
pungit ryhtyivätkin toimenpiteisiin kodinhoitopalvelun järjestämiseksi. Samalla koetettiin luoda järjestelmä, joka ulottuisi ja soveltuisi maaseudullekin. Vuoteen 1948 mennessä järjestettiin kodinhoitajia 123 kaupunkiin ja 16 kreivikuntaan maaseudulla. SuurLontoon alueella oli vuoden 1948 lopulla kodinhoitopalvelutyössä 560 henkilöä kokopäivätyössä ja 1370 henkilöä osapäivätyössä. Kuukauden kuluessa annettiin kodinhoitoapua keskimäärin 5900 perheeseen.

Englannin uusi kansallinen terveydenhoitolaki, joka koko laajuudessaan astui voimaan 5 päivänä heinäkuuta 1948 , määrää, että paikallisten terveydenhoitoviranomaisten on hankittava kodinhoitoapua sellaisiin talouksiin, joissa sitä tarvitaan jonkun henkilön sairauden, raskauden tai vanhuuden vuoksi tai joissa on alle kouluiän olevia lapsia. Mainitun lain turvin viranomaisilla on nyt mahdollisuus laajentaa kodinhoitopalvelua koskemaan ei ainoastaan sairaustapauksia, vaan myös auttamaan normaalitapauksissakin perheenäitiä, jolla on alaikäisiä lapsia. Väestökomitea pitääkin sellaista kodinhoitopalvelun laajentamista erittäin tärkeänä.

Kodinhoitopalvelun aiheuttamista kustannuksista suorittaa paikallinen viranomainen puolet ja terveysministeriö toisen puolen.

\section{Päiväkodit.}

Päiväkotitoiminta pääsi Englannissa alulle yksityisten järjestöjen aloitteesta. Sodan aikana sitä kehitettiin valtion toimesta, jotta äidit saisivat tilaisuuden käydä työssä. Kuntien hoidossa olevissa päiväkodeissa olevista lapsista äitien tuli suorittaa pieni maksu. Valtio puolestaan korvasi kunnille kaikki päiväkotien todelliset kustannukset. Vuonna 1945 oli toiminnassa noin 1400 päiväkotia, joissa oli noin 68000 lasta. Sodan päätyttyä valtion avustus alennettiin 50 prosenttiin kustannuksista. Sen jälkeen on päiväkotien lukumäärä,suuresti laskenut. Tämä ei ole johtunut yksinomaan valtionavun pienenemisestä, vaan myös siitä, että rakennukset ovat joutuneet taas rauhanaikaiseen käyttöönsä, mistä johtuen on ollut vaikeata saada sopivia huoneistoja päiväkodeille. 
Päiväkotikysymystä käsitellessään Englannin väestökomitea pitää toivottavana, että toimintaa kehitettäisiin siihen suuntaan, että $2-5$ vụotiaille lapsille tarjoutuisi tilaisuus olla osan päivästä päiväkodissa, jotta äiti siten saisi jonkin tunnin vapaa-ajan ostoksiaan ja askareitaan varten. Tällaisen tilapäisavun järjestämistä pidetään niin tärkeänä, että nykyinen päiväkotien yleisin muoto, työssä käyvien äitien lasten hoitaminen koko päivän ajan, saisi jäädä toissijaiseen asemaan osapäiväkotien rinnalla.

\section{Lastentarhat.}

Lastentarhat ovat nykyisin osa Englannin yleisestä koulujärjestelmästä. Koululaki velṽoittaa opetusviranomaisia järjestämään kaikille sitä haluaville tilaisuuden käydä lastentarhassa. Lastentarhat toimivat koulutuntien ajan viitenä päivänä viikossa lukukausien aikana. Huoneistopula on kuitenkin niidenkin kohdalla ollut esteenä toiminnan riittävälle laajentumiselle. Tilapäistoimenpiteenä on senvuoksi suositeltu sitä, että lastentarhat toimisivat kahdessa puolen koulupäivän vuorossa, jolloin ne voisivat ottaa vastaan puolta enemmän lapsia. Tulevaisuuden pyrkimyksenä on järjestää lastentarhaluokkia myös koulujen loma-aikoina, jotta äidit silloinkin saisivat kipeästi tarvitsemansa vapaa-ajan.

Lomakotitoiminta äitien ja lasten hyväksi.

Perheenäidit muodostavat sen väestönryhmän, joka loman saamiseen ja lomanviettomahdollisuuksiin nähden useimmiten on kaikkein huonoimmassa asemassa. Suuren perheen äidin rasittava ja hermoja kuluttava työ vaatisi välttämättä jonkin rauhallisen loma-ajan, mutta usein se näyttää olevan saavuttamattomissa. Kuka hoitaisi lapset loman aikana ja mistä saisi varat lomanviettoon?

Mainitun epäkohdan korjaamiseksi ovat monet vapaaehtoiset järjestöt tehneet parhaansa. Sopivista paikoista, usein meren ran- 
nalta, on hankittu rakennuksia, jotka on varustettu lomakodeiksi. Tällaisia äitien lomakoteja on useita esim. Church Army'lla ja Pelastusarmeijalla, mutta myös muilla järjestöillä. Osa kodeista on sellaisia, joihin vastaanotetaan vain äitejä. Toisiin koteihin äiti saa tuoda mukanaan 1-2 lastaan. Joihinkin koteihin äiti voi ottaa mukaansa kaikki lapset, ei kuitenkaan yli 8 vuotiaita poikia. Lomakotien henkilökunta hoitaa lapsia osan päivää ja pitää huolta heidän ruokailemisestaan, niin että äidit saavat syödä ateriansa rauhassa. Maksut lomakodeissa ovat hyvin halvat, ja useissa tapauksissa järjestö vielä antaa alennusta vähävaraisille perheille. Yleensä kestää oleskelu lomakodissa kaksi viikkoa. Useimmat kodit ovat melko pieniä, vain noin 40 äitiä ja lasta varten.

Joissakin kaupungeissa viranomaiset avustavat äitejä lomanviettokysymyksessä, mutta mitään yhtenäistä järjestelmää ei sillä alalla ole vielä olemassa. Uusien lomakotien perustamista vaikeuttaa varojen ja tarkoitukseen sopivien rakennusten puute. Aitien lomanviettokysymyksen ratkaisemista pidetään kiireellisenä ja ensiarvoisen tärkeänä toimenpiteenä. Tämän vuoksi väestökomiteakin esittää, että valtion taholta on ryhdyttävä toimenpiteisiin äitien lomanviettomahdollisuuksien tukemiseksi ja järjestämiseksi. 